\title{
ACINETOBACTER CELL BIOMASS, GROWTH STAGE AND PHOSPHORUS UPTAKE FROM ACTIVATED SLUDGE MIXED LIQUOR
}

\author{
T. E. Cloete and M. Bosch
}

\section{INTRODUCTION}

South Africa has limited water resources and it is therefore essential to prevent pollution so that the available water can be utilized optimally. Large concentrations of nutrients, such as phosphorus and nitrogen, in aquatic environments may cause excessive growth of photosynthetic plants and organisms, giving rise to a situation known as eutrophication. Since many algae can fix nitrogen, phosphorus is considered the most important growth limiting nutrient regarding eutrophication (Toerien el al., 1975). Due to the excessive phosphorus concentrations found in wastewaters, resulting from industrial effluents and domestic detergents, efficient phosphorus removal is essential. In South Africa the Water Act (Act no. 54, 1956) was therefore amended in 1980 to limit the orthophosphate concentration in effluents from wastewater treatment plants to $<1 \mathrm{mg} \mathrm{P} .1^{-1}$ (Slim, 1987). Biological phosphorus removal, which is gaining support worldwide, is an alternative to chemical phosphorus precipitation. Activated sludge plants have been developed for biological phosphorus removal (Barnard, 1976), but the prevention of eutrophication however remains a problem due to inadequate biological phosphorus removal. The phosphorus concentrations of effluents are currently being reduced to $<1 \mathrm{mg} \mathrm{P}$. $1^{-1}$ by additional chemical precipitation with $\mathrm{FeSO}_{4}$. Chemical precipitation however increases the operational cost of water treatment plants, not only as a result of the chemical cost but also the increased cost of sludge disposal. Another problem resulting from chemical precipitation is the increased salt concentration of the effluent which increases the mineralization of our aquatic environment. The need therefore exists to optimize biological phosphorus removal.

Acinetobacter has become the model organism for biological phosphorus removal since it was first isolated from a phosphorus removing activated sludge plant (Fuhs and Chen, 1975). Acinetobacter species can accumulate polyphosphates and, although not the only organism with this ability, they have been found to dominate in enhanced phosphorus removing activated sludge plants (Dienema et al., 1980; Buchan, 1983; Lötter, 1985; Streichan et al., 1990). Cloete and Steyn (1988b) found the average bacterial cell volume of volutin containing cells to be $1.0 \mu \mathrm{m}^{3}$, while the largest percentage of volutin containing cells only had a cell volume of between 0.50 and $0.59 \mu \mathrm{rn}^{3}$. Du Preez (1980) found that the cell volume and mass of A calcoaceticus increased with the growth rate, indicating that smaller cells had a reduced growth rate. From these results it would appear that phosphorus was accumulated mostly by the smaller cells, indicating that phosphorus removal by Acinetobacter could be influenced by the growth rate of the cells (Cloete and Steyn, 1988b).

The aim of this study was therefore to determine the relationship between cell biomass, phosphorus uptake and growth stage of different Acinetobacter isolates.

\section{MATERIALS AND METHODS}

Bacterial strains and culture conditions: Acinetobacter strains were obtained from culture collections and isolated from activated sludge according to the method of Bosch and Cloete (1993). The Acinetobacter strains received and isolated were identified further by numerical analysis of their total soluble cell protein profiles using sodium dodecyl sulphate gel electrophoresis (SDS-PAGE) of total soluble cell proteins and numerical analysis (Bosch and Cloete, 1993). The phosphorus uptake ability of the strains in mixed liquor was determined (Bosch and Cloete, 1993) and five of the strains exhibiting substantial phosphorus uptake were used in this study (Table 1). All strains were maintained on Nutrient agar (Biolab) slants at $40^{\circ} \mathrm{C}$ and subcultured monthly. 
TABLE 1. Acinetobacter Strains Used in Growth and Phosphorus Removal Studies

\begin{tabular}{lll}
\hline \multicolumn{1}{c}{ Strain } & \multicolumn{1}{c}{$\begin{array}{c}\text { SDS-PAGE } \\
\text { identification }\end{array}$} & \multicolumn{1}{c}{ Origin } \\
\hline$\varnothing 5$ & $\begin{array}{l}\text { Acinetobacter johnsonnii } \\
\text { AS60 }\end{array}$ & Dam \\
AS78 & $\begin{array}{l}\text { Acinetobacter lwoffii } \\
\text { subsp. baumannii }\end{array}$ & Activated sludge \\
AS93 & Acinetobacter Iwoffii & Activated sludge \\
ATCC $^{\mathrm{b}} 17908^{\mathrm{T}}$ & Acinetobacter junii $^{\text {Acinated sludge }}$ & Activater \\
\hline
\end{tabular}

a Identified by Bosch and Cloete (1993)

b American type culture collection (ATCC, Rockville, Maryland 20852, U.S.A.); Type strain of $A$. junii.

Growth studies: Mixed liquor obtained from the anaerobic tank of a five stage Bardenpho activated sludge plant was centrifuged in a Sorval RC-5B centrifuge at $5000 \mathrm{~g}$ for $20 \mathrm{~min}$. Mixed liquor medium (ML medium) was prepared according to a modified version of the acetate enrichment medium of Fuhs and Chen (1975) as follows: the supernatant from the centrifuged mixed liquor was prefiltered through Watman No. 1 filter paper and either $200 \mathrm{mg} \cdot \mathrm{l}^{-1}$ or $5 \mathrm{~g} . \mathrm{l}^{-1}$ sodium acetate (BDH), $0.5 \mathrm{~g} . \mathrm{l}^{-1} \mathrm{MgSO}_{4} .7 \mathrm{H}_{2} \mathrm{O}$ (Merck) and $0.18 \mathrm{~g} .1^{-1} \mathrm{KNO}_{3}$ (Merck) were added and the $\mathrm{pH}$ adjusted to $\mathrm{pH} 7$ with $2 \mathrm{~N}$ HCL, before autoclaving $\left(121^{\circ} \mathrm{C}, 15 \mathrm{~min}\right)$. This ML medium was used for all growth and phosphorus uptake studies. For each isolate tested, two erlenmeyer flasks containing $96 \mathrm{ml}$ sterile ML medium was inoculated with $4 \mathrm{ml}$ of a culture, cultured in Nutrient broth, incubated for $48 \mathrm{~h}$ at $28^{\circ} \mathrm{C}$ with shaking $(80 \mathrm{rpm})$ and placed in a shaking waterbath $(80 \mathrm{rpm})$ at $28^{\circ} \mathrm{C}$. Growth was monitored by using one flask for absorbance determinations at $550 \mathrm{~nm}$, while the second was used for viable count determinations.

Phosphorus uptake studies: Phosphorus accumulation was monitored by analysis of the phosphorus content of the medium and by determining whether polyphosphate granules were present in the cells, using transmission electron microscopy (TEM). The phosphorus content of the medium was analyzed by removing $1.0 \mathrm{ml}$ samples from the flasks and filtering the samples through $0.22 \mu \mathrm{m}$ filters (Millipore) to remove all cells. Uninoculated ML medium was used as control and treated in the same manner as the inoculated ML medium. The phosphorus content of the filtered medium was then determined with the P(VM) 14842 test kit (Merck), using the Merck SQ 118 Photometer.

TEM studies: Separate flasks were inoculated and treated in the same manner as the flasks used for the growth and phosphorus uptake studies. The contents of the flasks were centrifuged at $9000 \mathrm{~g}$, for $10 \mathrm{~min}$, to obtain a cell pellet which was then fixed, overnight at $4^{\circ} \mathrm{C}$, in a solution containing $2.0 \%$ glutaraldehyde in $0.1 \mathrm{M}$ sodium cacodylate buffer. The cells were then washed in $0.1 \mathrm{M}$ sodium cacodylate buffer for $15 \mathrm{~min}$. The washing process was repeated for three changes of buffer before post fixation in $0.25 \%$ osmium tetroxide for $60 \mathrm{~min}$. The cells were washed again $(15 \mathrm{~min})$ with three changes of $0.1 \mathrm{M}$ sodium cacodylate buffer and then dehydrated for $15 \mathrm{~min}$ at each concentration in a graded alcohol series (50, 70, 90 and 3x100\% ethanol). Infiltration with 33\% Quetol resin took place for $60 \mathrm{~min}$ followed by $66 \%$ Quetol resin for another $60 \mathrm{~min}$ and finally $100 \%$ Quetol resin for $4 \mathrm{~h}$. The suspensions were then transferred to Beem capsules, centrifuged to obtain a pellet and the resin removed. Quetol resin (100\%) added to each Beem capsule and allowed to infiltrate for $18 \mathrm{~h}$ before being placed in an oven at $65^{\circ} \mathrm{C}$ for at least $48 \mathrm{~h}$ to allow the resin to polymerize. Silver-gold sections were obtained using a Reichett-Jung ultramicrotome with a diamond knife. Staining of the ultrathin sections was accomplished by placing them on copper grids and floating the grids on lead citrate for $10 \mathrm{~min}$ and $6 \%$ aqueous uranyl acetate for $3 \mathrm{~min}$. The stained sections were examined on a Hitachi $\mathrm{H} 600$ transmission electron microscope at $50 \mathrm{KV}$.

Cell size determinations. The cell volumes were determined directly from the electron micrographs, taking into account the magnification factor, according to the method of Cloete and Steyn (1988b).

\section{RESULTS AND DISCUSSION}

Growth and phosphorus accumulation of Adnetobacter strains in activated sludge mixed liquor. Although strains 5 and AS93 were capable of limited growth in the mixed liquor medium, 
containing $200 \mathrm{mg} . \mathrm{l}^{-1}$ sodium acetate, very small quantities of phosphorus were removed from the medium (Figs 1-2).

Acinetobacter strains AS 60, AS 78, AS 93, ATCC 17908 and 5 all had the ability to grow and remove phosphorus in the mixed liquor medium containing $5 \mathrm{~g} . \mathrm{H}$ sodium acetate (Figs 3-7).

A lag phase of ca. $5 \mathrm{~h}$ was observed for all strains investigated and the stationary phase was reached after 10 and $14 \mathrm{~h}$ of growth. The absorbance readings were supported by the viable count trends (Table 2). The phosphorus removed from the medium was accumulated as intracellular polyphosphate inclusions, in the cells of strain AS93 and 5 after 4 and $7 \mathrm{~h}$ respectively (Fig. 8).

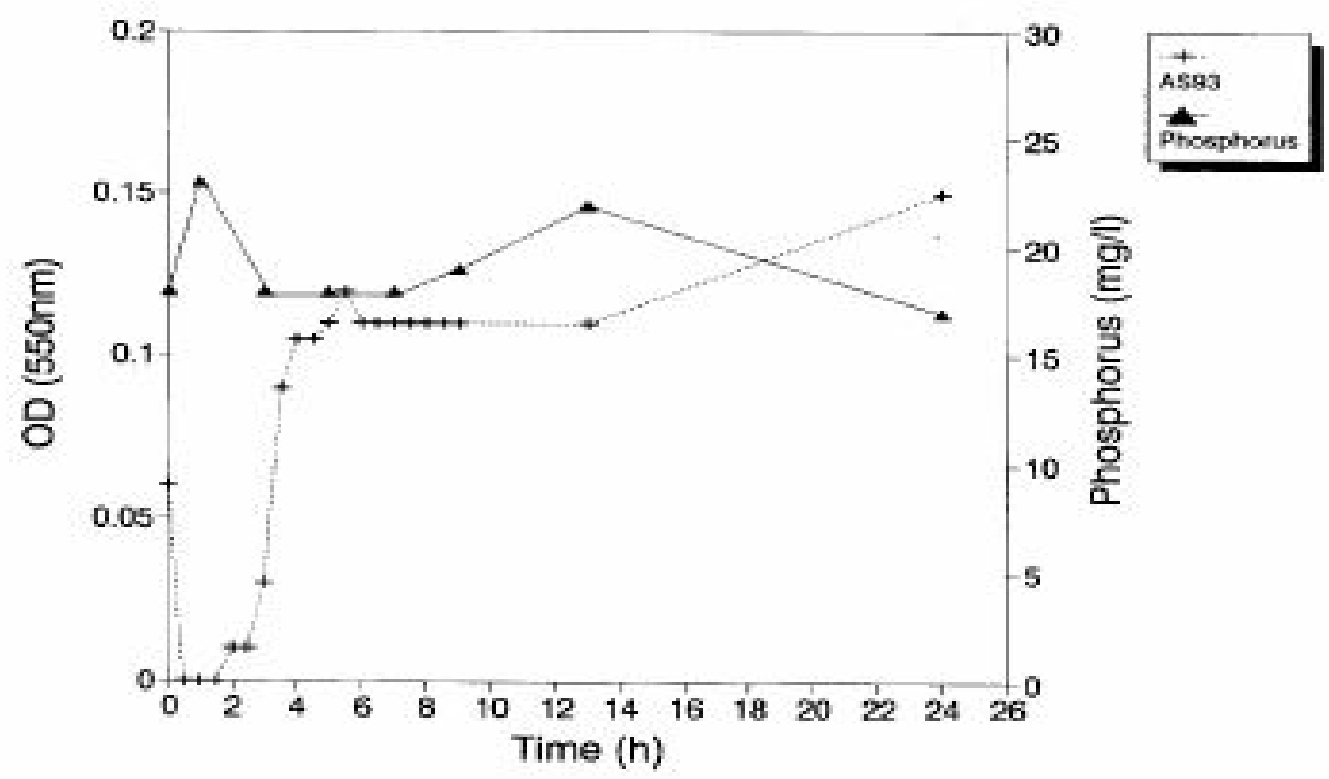

Fig. 1. Growth and phosphorus uptake of A. lwoffii strain AS93 in mixed liquor medium ( $200 \mathrm{mg} / 1$ sodium acetate).

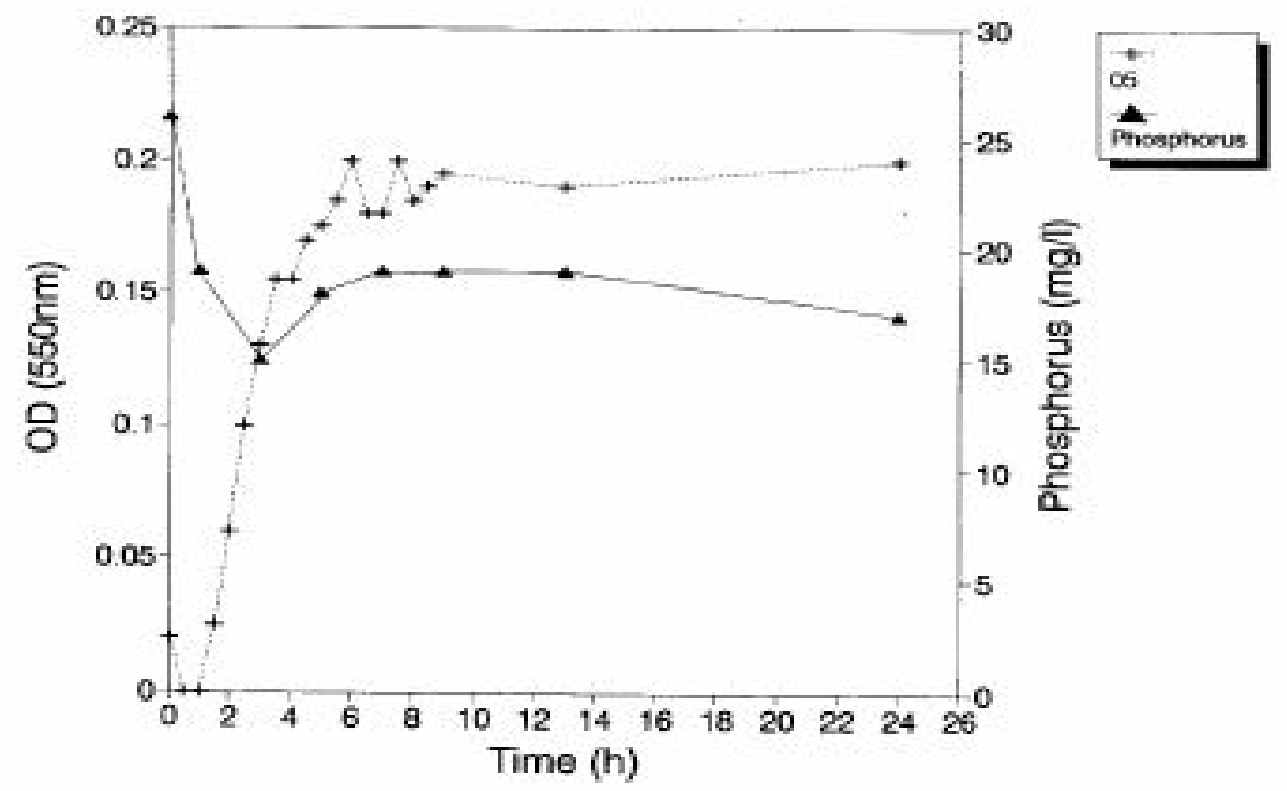

Fig. 2. Growth and phosphorus uptake of $A$. jolinsonnii strain $ø 5$ in mixed liquor medium ( $200 \mathrm{mg} / 1$ sodium acetate). 


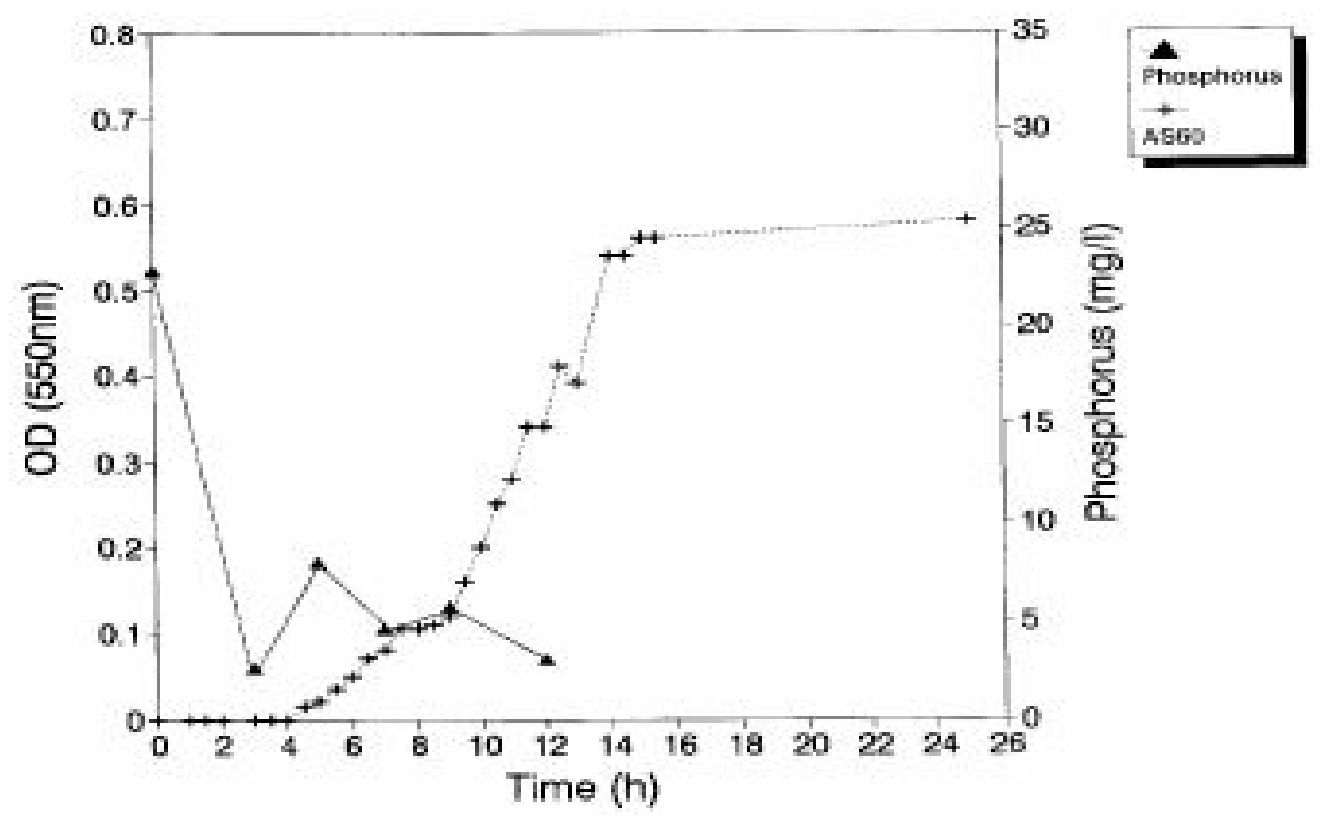

Fig. 3. Growtli and phosphorus uptake or A. lwoffti strain AS60 in mixed liquor medium (5 g/1 sodium acetate).

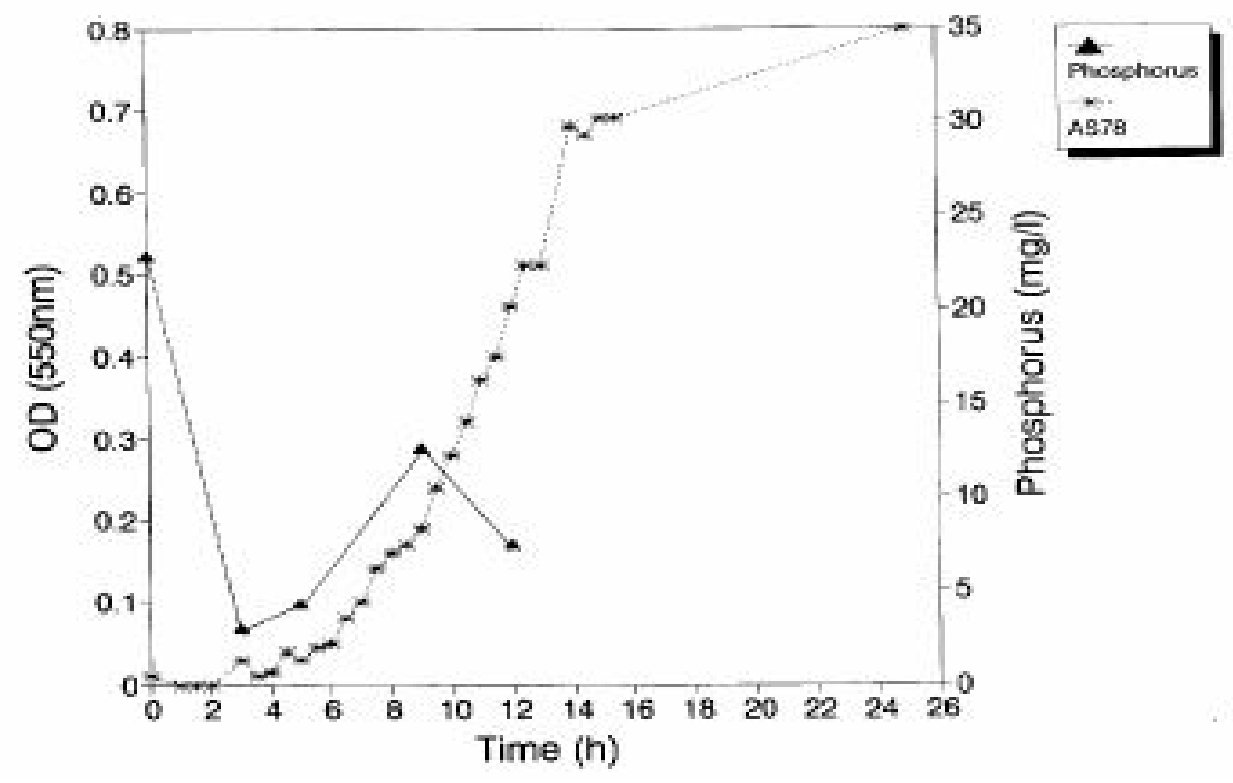

Fig. 4. Growth and phosphorus uptake of $A$. calcoaceticus subsp. baumannii strain AS 78 in mixed liquor medium ( $5 \mathrm{~g} / 1$ sodium acetate). 


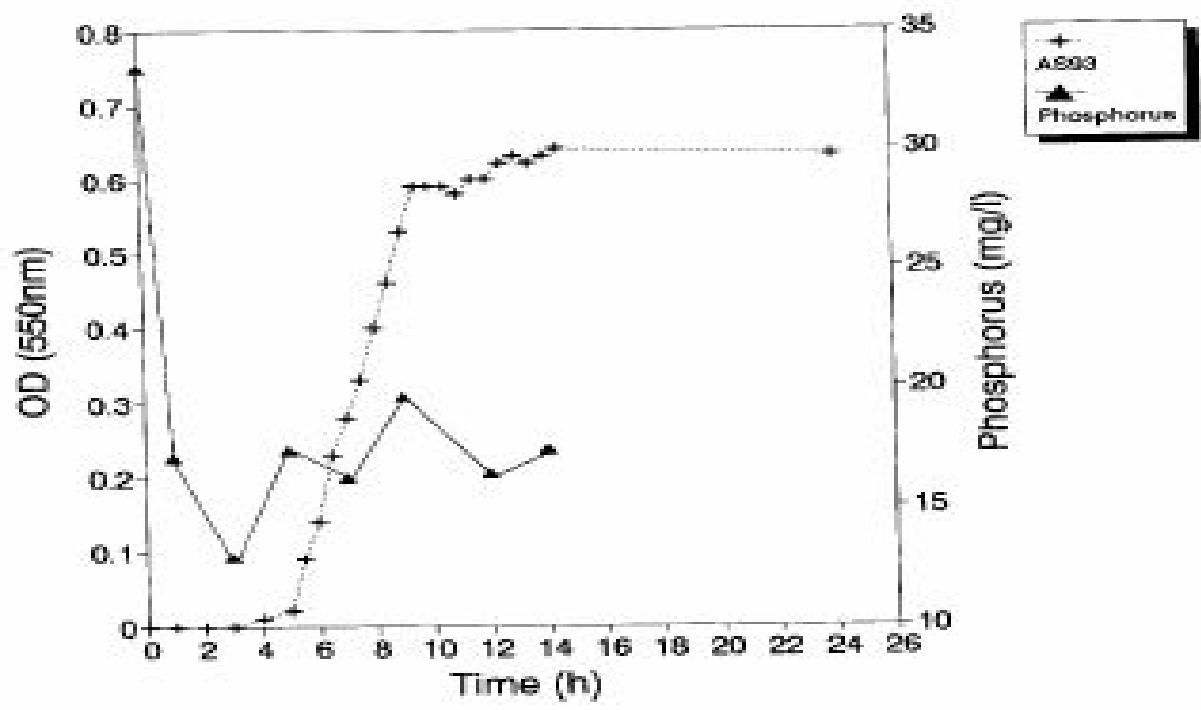

Fig. 5. Growth and phosphorus uptake of $A$. lwoffii strain AS93 in mixed liquor medium (5 g/l sodium acetate).

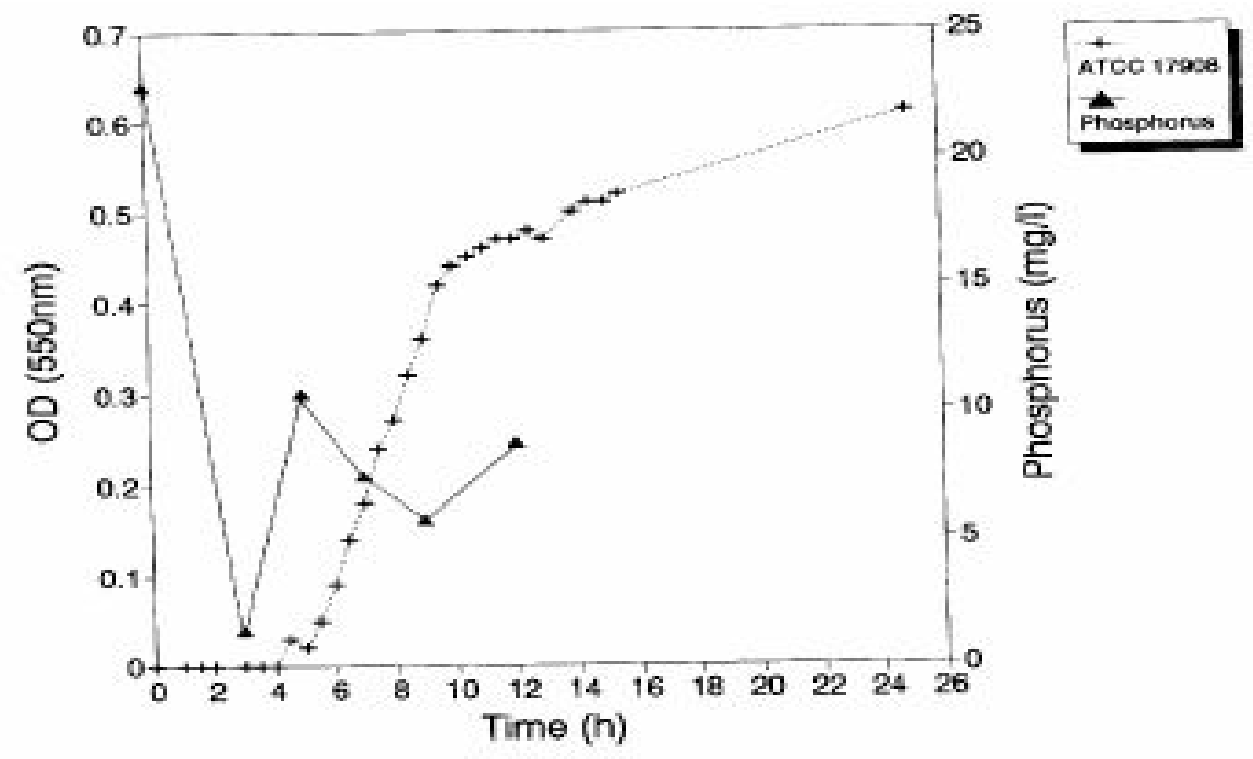

Fig. 6. Growth and phosphorus uptake of $A$. junii strain ATCC 17908 in mixed liquor medium (5 g/1 sodium acetate). 


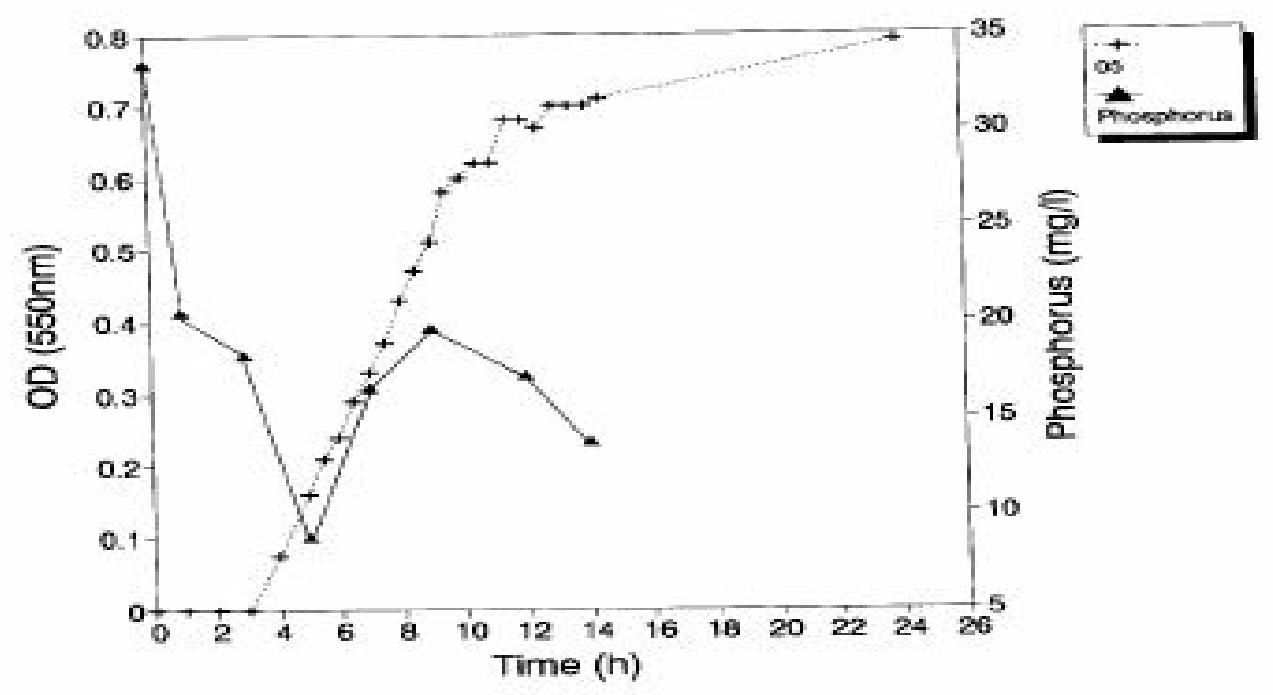

Fig. 7. Growth and phosphorus uptake of A. johnsonnii strain $\mathrm{f} 5$ in mixed liquor medium ( $5 \mathrm{~g} / 1$ sodium acetate).

From the results it would appear that most of the phosphorus was accumulated in the lag phase, which is a period of adjustment prior to the onset of cell division. During this period the cells synthesize the cellular components, enzymes and metabolic intermediates needed for cell synthesis. If cells are transferred to a medium of different composition, the biosynthetic pathways needed for the production of the metabolites not present, or for the utilization of those different metabolites present in the new medium, will be synthesized during the lag phase (Van Denmark and Batzing, 1987). Although there was no increase in cell numbers during this phase the cells were metabolically active and were capable of phosphorus uptake. Since no active growth occurs in the lag phase the cells will be relatively small and phosphorus uptake in this phase of growth would explain the observation that smaller cells mostly contained polyphosphate granules ( $\mathrm{Du}$ Preez, 1980; Cloete and Steyn, 198Xb). Just prior to and during the initiation of the logarithmic growth phase a portion of the accumulated phosphorus was released. Some of the phosphorus released was then accumulated again near the end of logarithmic growth and during the stationary phase. These results correspond to results for an Aerobacter aerogenes culture in which it was determined that a reciprocal relationship exists between polyphosphate accumulation and nucleic acid synthesis (Harold, 1963). The author postulated that once nucleic acid synthesis began (i.e growth) competition for the available phosphorus would prevent the accumulation of polyphosphate (Harold, 1963). The definition of the 'luxury uptake' of phosphorus, as observed in activated sludge, is that excessive quantities of phosphorus are accumulated once growth has been arrested due to the lack of some nutrient (Fuhs and Chen, 1975). These results not only confirm that polyphosphate accumulation takes place only when cells are not actively multiplying, but also indicate that phosphorus accumulation occurred as part of the natural growth cycle (i.e. lag phase) and stress conditions (e.g lack of nutrients) were not a prerequisite for 'luxury uptake', but rather that the cells have a natural affinity to store polyphosphate.

A lower nutrient environment (i.e. $200 \mathrm{mg}^{-1} \mathrm{l}^{-1}$ sodium acetate) resulted in less phosphorus removal from the medium, yet the quantity accumulated per cell was comparable to that of the corresponding strain cultured in ML medium containing $5 \mathrm{~g}$. $1^{-1}$ sodium acetate (Table 2). 
TABLE 2. Viable Counts and Phosphorus Uptake of Acinetobacter Strains in Mixed Liquor Medium*

\begin{tabular}{|c|c|c|c|c|}
\hline \multirow[t]{2}{*}{ Strain } & \multicolumn{2}{|c|}{$\begin{array}{l}\text { Viable count } \\
\text { CFU.mll }\end{array}$} & \multirow{2}{*}{$\begin{array}{c}\text { Phosphorus } \\
\text { (P) } \\
\text { uptake } \\
\text { mg. }^{-1}\end{array}$} & \multirow{2}{*}{$\begin{array}{l}\text { Phosphorus } \\
\text { (P) } \\
\text { uptake }^{b} \\
\text { mg.cell }\end{array}$} \\
\hline & $\begin{array}{l}\text { Before } \\
\text { incubation }\end{array}$ & $\begin{array}{l}\text { After } \\
\text { incubation }^{\mathrm{c}}\end{array}$ & & \\
\hline Free cells [a] & \multicolumn{4}{|c|}{ (200 mg. $\mathrm{l}^{-1}$ sodium acetate) } \\
\hline$\varnothing 5$ & $5.8 \times 10^{7}$ & $2.43 \times 10^{8}$ & 9.00 & $3.7 \times 10^{-11}$ \\
\hline AS93 & $8.7 \times 10^{6}$ & $1.27^{\mathrm{x}} 10^{8}$ & 1.00 & $7.8 \times 10^{-12}$ \\
\hline Free cells $[\mathrm{b}]$ & \multicolumn{4}{|c|}{ (5 g. $1^{-1}$ sodium acetate) } \\
\hline$\varnothing 5$ & $2.24 \times 10^{7}$ & $1.31 \times 10^{9}$ & 20.00 & $1.51 \times 10^{-11}$ \\
\hline AS60 & $1.38 \times 10^{6}$ & $8.66 \times 10^{9}$ & 20.00 & $2.29 \times 10^{-12}$ \\
\hline AS78 & $2.40 \times 10^{7}$ & $7.35 \times 10^{8}$ & 15.00 & $2.09 \times 10^{-11}$ \\
\hline AS93 & $1.23 \times 10^{7}$ & $9.05 \times 10^{8}$ & 16.00 & $1.78 \times 10^{-11}$ \\
\hline 17908 & $2.86 \times 10^{7}$ & $8.80 \times 10^{8}$ & 14.00 & $1.60 \times 10^{-11}$ \\
\hline
\end{tabular}

${ }^{\mathrm{a}}\left[\mathrm{P}\right.$ uptake $\left.\left(\mathrm{mg} \cdot \mathrm{l}^{-1}\right)\right]=\left[\mathrm{P}\right.$ uninoculated control $\left.\left(\mathrm{mg} \cdot \mathrm{l}^{-1}\right)\right]-\left[\mathrm{P}\right.$ sample $\left.\left(\mathrm{mg} \cdot \mathrm{I}^{-1}\right)\right]$

$\mathrm{b}\left[\mathrm{P}\right.$ uptake.cell $\left.{ }^{-1}\right]=\left[\mathrm{P}\right.$ uptake $\left.\left(\mathrm{mg} . \mathrm{l}^{-1}\right)\right] \div\left[\right.$ CFU.ml ${ }^{-1}$ after incubation $\left.\mathrm{x} 1000\right]$

${ }^{\mathrm{c}}$ Free cells: [a] Strains AS 93 and $\varnothing 5: 24 \mathrm{~h}$

[b] Strains AS60, AS78 and 17908: 13h;

Strain $\varnothing 5$ and AS93: $12 \mathrm{~h}$

Similar quantities of phosphorus were removed per cell, i.e. $3.7 \times 10^{-11}$ and $1.51 \times 10^{-11} \mathrm{mg}^{-c e l l^{-1}}$ for strain 5, in ML medium containing $200 \mathrm{mg} .1^{-1}$ and 5 g. $1^{-1}$ sodium acetate respectively. This suggests that cells may be limited to a certain quantity of polyphosphate uptake irrespective of the substrate availability. This polyphosphate limit may however differ between the different strains and would account for the variations in phosphorus accumulated. Higher substrate concentrations would therefore lead to greater phosphorus removal due to the resultant biomass increase (i.e. 9 mg. $l^{-1}$ versus $20 \mathrm{mg} . \mathrm{l}^{-1}$ for strain 5) (Table 2).

Soil, water and sewage, being the natural habitat of these organisms, are environments subject to large fluctuations in nutrient availability which would explain the evolution of polyphosphate accumulation as a storage mechanism for times when its availability is low, thereby providing the organisms with a selective advantage. In the biochemical model for polyphosphate accumulation as proposed by Wentzel et al. (1986), in a completely aerobic environment where the Krebs cycle is active, the ATP/ADP ratio will be sufficiently high to supply the energy for polyphosphate accumulation provided sufficient substrate is available. The protons and electrons required would be supplied by the operation of the Krebs cycle. This was supported by our findings that phosphorus was accumulated in a completely aerobic environment. An average of ca. $17.06 \mathrm{mg} \mathrm{l}^{-1}$ of the phosphorus was removed from the medium by the five strains tested, with a maximum of $19.9 \mathrm{mg} . \mathrm{l}^{-1}$ being removed by strain AS60 and a minimum of $14.1 \mathrm{mg} . \mathrm{l}^{-1}$ by ATCC 17908 (Table 2). Although strain AS60 removed the largest quantity of phosphorus from the medium, in relation to biomass, it accumulated the least per cell, while strain 5 accumulated the most per cell. The larger quantity of phosphorus removed was therefore a function of the larger cell numbers and not due to a greater affinity of the cells for polyphosphate accumulation. This suggests that biomass is critically important to phosphorus removal. Acinetobacter strain 5 therefore effectively accumulated the most phosphorus per cell (Table 2). Nutrient availability would therefore appeal ${ }^{-}$ to enhance phosphorus uptake by virtue of the increased biomass and not due to an enhanced accumulation per cell. 
The TEM photographs show that the phosphorus removed from the medium was accumulated by the bacteria as intracellular polyphosphate granules (Fig. 8).
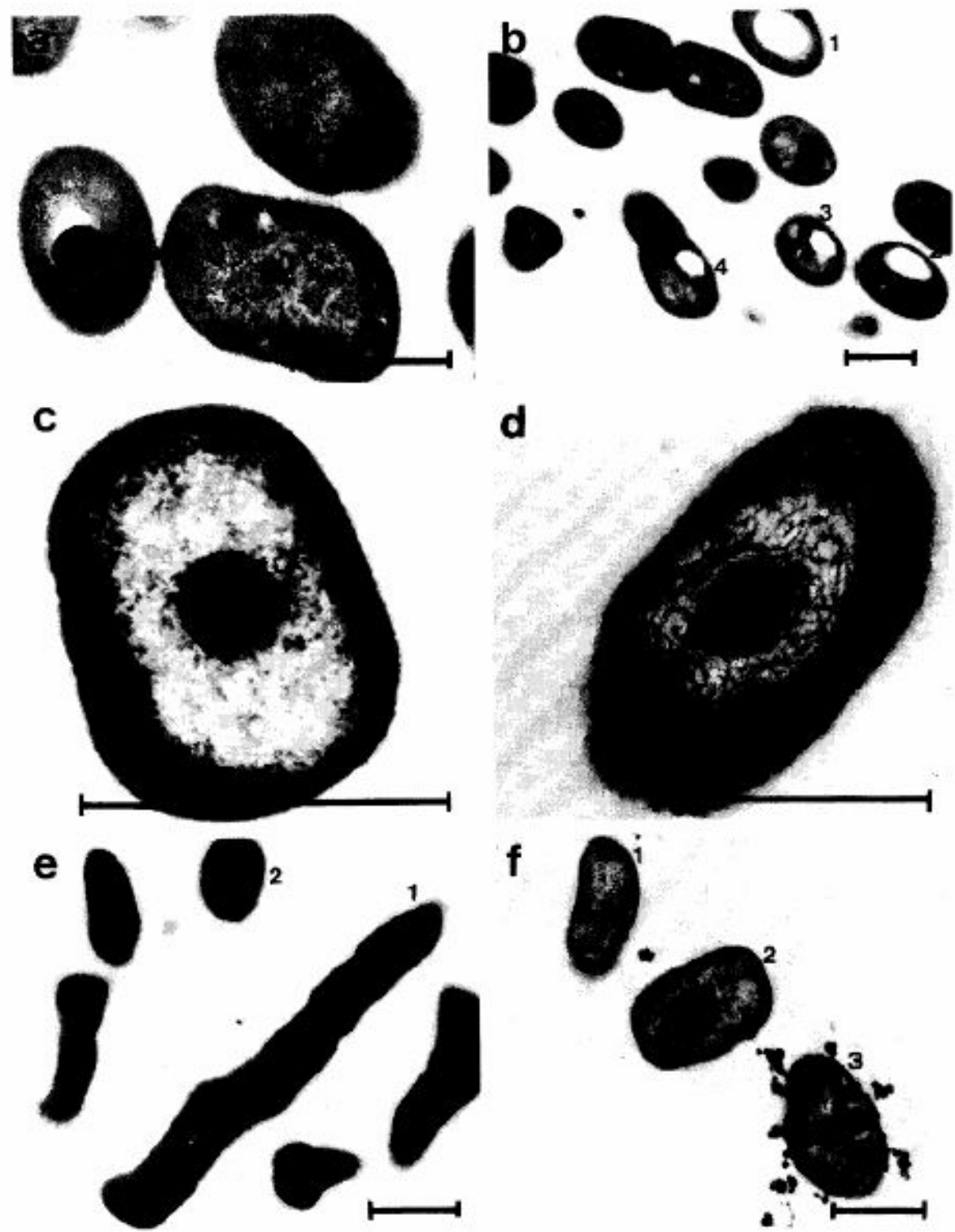

Fig. X. TEM photugraphs of Acinetobacter strains f5 and AS93 showing intracellular polyphosphate granules: (a) Stritin AS93 after 4 h $135(\times 0) \times 1$; (b) Strain AS93 after 4h, the transluoent boles are where the polyphosphate granules were ripped out during sectioning $(15000 \mathrm{x})$; (c) Strain AS93 after $7 \mathrm{~h}(80000 \mathrm{x})$; (d) Strain f5 after $7 \mathrm{~h}$ ( 600 (ino $x$ ); (e) Strain 15 after $7 \mathrm{~h}$, showing pleomorphism $(20000 \mathrm{x})$; (f) Strain 65 after $9 \mathrm{~h}$ still contained polyphosphate granules $120(0 \times 0)$ ). In each electron micrograph the har represents Imun. 
The phosphorus concentration of the mixed liquor medium decreased dramatically in the first $5 \mathrm{~h}$, i.e. the lag phase (Figs 3-7), and polyphosphate granules were already observed at $4 \mathrm{~h}$ (Fig. 8a,b,c). Although there were slight fluctuations in the phosphorus content of the medium, the cells still contained polyphosphate granules at 7 and $9 \mathrm{~h}$ which was expected since the system was aerobic and phosphorus release was therefore not expected.

Bergy's manual (Juni, 1984) states that the average length of Acinetobacter cells is $1.5-2.5 \mu \mathrm{m}$. The cells in this study, containing polyphosphate granules, were ca. 1.0-1.5 $\mu \mathrm{m}$ in length (Fig. 8), indicating that cells with polyphosphate granules were mostly relatively small cells. Due to the cocco-bacilli shape and pleomorphic nature of Acinetobacter cell length alone is not a good measure of size, therefore the cell volume was determined (Table 3). Cloete and Steyn (1988b) found that most of the polyphosphate containing cells had a cell volume of $0.5-0.59 \mu \mathrm{m}^{3}$ or less. The frequency distribution of the cell volumes (Table 4) clearly indicates that most of the cells with polyphosphate granules are very small with cell volumes of between $0.1-1.9 \mu \mathrm{rn}^{3}$. It was therefore concluded that small slow growing cells accumulated polyphosphate. Pleomorphic Acinetobacter cells, containing polyphosphate granules, were found after $7 \mathrm{~h}$ (Fig. 8e). The pleomorphic nature of Acinetobacter has been noted before as a result of oxygen deficiency (Du Preez, 1980). Du Preez (1980) suggested, that as the cell density increased during growth, the oxygen uptake rate increased and the oxygen transfer rate would eventually become the growth limiting factor. The dissolved oxygen concentration was however not determined in this study. The pleomorphic cells were however noted after $7 \mathrm{~h}$ incubation at which time the cells were in the logarithmic growth phase and oxygen transfer could have been limiting due to the increased cell density as suggested by Du Preez (1980). Du Preez (1980) also found that oxygen limitation alone could not induce pleomorphism and that the growth rate did not play a role in this phenomenon.

TABLE 3. Cell Volume of Acinetobacter Cells Containing Polyphosphate Granules

\begin{tabular}{l|cc}
\hline $\begin{array}{c}\text { Electron } \\
\text { micrograph* }\end{array}$ & Strain & $\begin{array}{c}\text { Cell volume } \\
\mu \mathrm{m}^{3}\end{array}$ \\
\hline $\mathrm{a}$ & AS93 & 0.65 \\
$\mathrm{~b}(1)$ & AS93 & 0.22 \\
$\mathrm{~b}(2)$ & AS93 & 0.17 \\
$\mathrm{~b}(3)$ & AS93 & 0.12 \\
$\mathrm{~b}(4)$ & AS93 & 0.18 \\
$\mathrm{c}$ & AS93 & 3.29 \\
$\mathrm{~d}$ & $\varnothing 5$ & 2.53 \\
$\mathrm{e}(1)$ & $\varnothing 5$ & 0.53 \\
$\mathrm{e}(2)$ & $\varnothing 5$ & 0.10 \\
$\mathrm{f}(1)$ & $\varnothing 5$ & 0.14 \\
$\mathrm{f}(2)$ & $\varnothing 5$ & 0.48 \\
$\mathrm{f}(3)$ & $\varnothing 5$ & 0.28 \\
\hline
\end{tabular}

*See Fig. 8. 
TABLE 4. Frequency Distribution For The Size Of Polyphosphate Containing Acinetobacter Cells

\begin{tabular}{ccc}
\hline Cell volume $\left(\mu \mathrm{m}^{3}\right)$ & Number of cells & $\%$ of total \\
\hline $0.10-0.19$ & 5 & 41.67 \\
$0.20-0.29$ & 2 & 16.67 \\
$0.30-0.39$ & 0 & 0 \\
$0.40-0.40$ & 1 & 8.34 \\
$0.50-0.59$ & 1 & 8.34 \\
$0.60-0.69$ & 1 & 8.34 \\
$0.70-0.79$ & 0 & 0 \\
$0.80-0.89$ & 0 & 0 \\
$0.90-0.99$ & 0 & 0 \\
$>1.0$ & 2 & 16.67
\end{tabular}

Growth rate did however influence the cell size. Slow growing cells were smaller than fast growing cells (Du Preez, 1980). The cells containing polyphosphate were relatively small, indicating a slow growth rate, especially since phosphorus was mostly accumulated in the lag phase when the cells were not actively growing.

\section{ACKNOWLEDGEMENTS}

The authors would like to acknowledge and thank the Water Research Commission for financial support which made this study possible.

\section{REFERENCES}

Barnard, J. L. (1976). A review of biological phosphorus removal in the activated sludge process. Water SA, 2 , 136-144.

Bosch, M. and Cloete, T. E. (1993). The identification and classification of Acinetobacter strains exhibiting variations in phosphate accumulation using SDS-PAGE and numerical analysis. Current Microbiology, 27, $169-174$.

Buchan, L. (1983). Possible biological mechanism of phosphorus removal. Wat. Sci. Tech., 15(3/4), 87-103.

Buchan, L. (1984). Microbiological aspects In: Theory, Design and Operation of Nutrientremoval Activated Sludge Processes, H. N. S. Wiechers, G. A. Ekama, A. Gerber, G. F. P. Keay, W. Malan, G. v. R. Marais, D. W. Osborn, A. R. Pitman, D. J. J. Potgieter, W. A. Pretorius (eds.), Water Research Commission, Pretoria, South Africa, p. 9.1-9.6.

Cloete, T. E. and Steyn, P. L. (1988a). A combined membrane filter-immunofluorescent technique for the in situ identification of Acinelobacter in activated sludge. Wat. Res., 22(8), 961-969.

Cloete, T. E. and Steyn, P. L. (1988b). The role of Acinetobacler as a phosphorus removing agent in activated sludge. Wat. Res. 22(81,971-976.

Cloete, T. E., Bosch, M. and Mienie, N. J. J. (1992). Organisms other than Acinetobacter capable of phosphorus removal from activated sludge mixed liquor. Paper presented at the European Conference on Nutrient Removal from Wastewaters, September, 1992, Leeds, U.K.

Deinema, M. H., Habets, L. H. A., Scholten, J., Turkstra, E. and Webers, H. A. A. M. (1980). The accumulation of polyphosphate in Acinetobacter spp. FEMS Microbiol. Lett. 9, 275-279.

Du Preez. J. C. (1980). Growth kinetics of Acinetobacter calcoaceticus with special reference to acetate and ethanol as carbon sources. Ph.D thesis, University of the Orange Free State, Bloemfontein, South Africa. 
Fuhs, G. W. and Chen, M. (1975). Microbiological basis of phosphate removal in the activated sludge process for the treatment of wastewater. Microbial Ecology, 2, 119-138.

Harold, F. M. (1963). Accumulation of inorganic polyphosphate in Aerobacter aerogenes. 1. Relationship to growth and nucleic-acid synthesis. J. Bacterial. 86, 216-221.

Juni, E. (1984). Genus III. Acinelobacter Brisou and Prèvot 1954 In: Bergey's Manual of systematic

bacteriology, vol. 1. N. R. Krieg and J. G. Holt (ed.). The Williams and Wilkins Co., Baltimore, p. 303-307.

Lötter, L. H. (1985). The role of bacterial phosphate metabolism in enhanced phosphorus removal from the activated sludge process. Wat. Sci. Tech., 17(11/12), 127-138.

Slim, J. A. (1987). Some developments in the water industry in South Africa. J. Wat. Pollut. Control, 86(2), 262-271.

Toerien, D. F., Hyman, K. L. and Bruwer, M. J. (1975). A preliminary tropic status classification of some of South African impoundments. Water $S A, 1(1), 15-23$.

Van Denmark, P. J. and Batzing, B. L. (1987). The mMicrobes: An Introduction to their Nature and Importance. The Benjamin/Cummings Publishing Co., Inc., Menlo Park, California, USA.

Wentzel, M. C., Lötter, L. H., Loewenthal, R. E. and Marais, G. v.R. (1986) Metabolic behaviour of Acinetobacter spp. in enhanced biological phosphorus removal - a biochemical model. Water SA, 12(4), $209-224$. 